\title{
Furcocercous cercariae (Trematoda) from freshwater snails in Central Finland
}

\author{
Anna Faltýnková1,4* ${ }^{*}$, Katarzyna Niewiadomska², Maria J. Santos ${ }^{3}$ and E. Tellervo Valtonen 4 \\ ${ }^{1}$ Biology Centre, Academy of Sciences of the Czech Republic, Institute of Parasitology, Branišovská 31, 37005 České Budějovice, \\ Czech Republic; ${ }^{2}$ W. Stefański Institute of Parasitology, Polish Academy of Sciences, Twarda 51/55, 00-818 Warszawa, Poland; \\ ${ }^{3}$ Department of Zoology and Anthropology, Faculty of Sciences, University of Porto, Praça Gomes Teixeira, \\ 4099-002 Porto/CIIMAR - CIIMAR Porto, Portugal; ${ }^{4}$ Department of Biological and Environmental Science, \\ University of Jyväskylä, P.O. Box 35 (YA), Fin-40014, Finland
}

\begin{abstract}
A total of eight species of furcocercous cercariae of four families (Strigeidae, Diplostomidae, Schistosomatidae and Sanguinicolidae), were found in 2005 in Lake Konnevesi in Central Finland in four snail species (Valvata macrostoma, Lymnaea stagnalis, Bathyomphalus contortus and Planorbarius corneus). Australapatemon burti (Miller, 1923), Australapatemon sp., Cotylurus brevis Dubois et Rausch, 1950, Cercaria spinulosa Ginetsinskaya, 1959 and Sanguinicola sp. are new species records for Finland. Ichthyocotylurus variegatus (Creplin, 1825) and Bilharziella polonica (Kowalewski, 1895) were first recorded as cercariae in Finland. The most common cercariae were A. burti (prevalence 13.3\%) and Diplostomum pseudospathaceum Niewiadomska, $1984(10.0 \%)$. Our study represents the first host record of Valvata macrostoma for larval stages of Australapatemon sp. and Sanguinicola sp.
\end{abstract}

\section{Keywords}

Trematoda, cercariae, Mollusca, Pulmonata, Prosobranchia, Valvata macrostoma, Finland

\section{Introduction}

Although a significant part of Finland is covered by lakes, the knowledge on the freshwater larval trematodes is relatively limited. The first study on the trematodes with freshwater life cycles was published by Wikgren (1956) who summarized the data on larval trematodes (28 species in total) occurring in southwestern Finland including the scattered data of previous Finnish investigations. After a long gap, ecological aspects of trematode communities of five species occurring in bivalves and their host-parasite relationships were studied by the group of Valtonen (Taskinen et al. 1991, 1994, 1997; Gibson et al. 1992; Holopainen et al. 1997; Rantanen et al. 1998). The investigations on the cercarial fauna of Lymnaea spp. by Niewiadomska et al. (1997) in Central Finland and Väyrynen et al. (2000) in a more northern area revealed another five species, which were new records for Finland. Recently, during ecological studies focused on Diplostomum spp., another species was found (Karvonen et al. 2004, 2006a, b). Based on previous studies, so far cercariae of 39 trematode species of 16 families are known to infect molluscs in Finland.
In 2005, trematodes of three pulmonate snails (Lymnaea stagnalis, Bathyomphalus contortus, Planorbarius corneus) and the prosobranchiate Valvata macrostoma, previously not examined in Finland, were studied in Lake Konnevesi (Central Finland). This study presents eight furcocercous cercariae with descriptions and illustrations of new species records and new records of cercariae in Finland.

\section{Materials and methods}

The study was conducted in Lake Konnevesi $\left(62^{\circ} \mathrm{N}, 26^{\circ} \mathrm{E}\right)$, at the bay near Siikakoski rapids at the Konnevesi Research Station of University of Jyväskylä. Konnevesi is a large oligotrophic lake in Central Finland with an area of $113 \mathrm{~km}^{2}$ and mean depth of $13 \mathrm{~m}$ (maximum depth $56 \mathrm{~m}$ ).

Samples of molluscs were collected in August 2005. Lymnaea stagnalis were collected by hand from shallow water or by snorkeling to the depth of $1 \mathrm{~m}$ from the littoral zone. Valvata macrostoma, Lymnaea stagnalis, Bathyomphalus contortus and Planorbarius corneus were collected using grab 
samples in shallow water near the pier of the research station (see sample sizes in Table I).

In the laboratory the snails were separated into vials with a small amount of lake water. Shedding of cercariae was stimulated by light and heat for 4-6 hours. Live cercariae were observed under light microscope using vital staining with neutral red and Nile blue. For measurements the cercariae were fixed in hot $4 \%$ formaldehyde solution. Measurements are in micrometres expressed as the range with mean in parentheses. The number of measurements per parasite species ranged from 10 to 20 .

The nomenclature of snails follows that of Glöer (2002). The trematode species are listed according to the nomenclature and systematics used in Gibson et al. (2002).

\section{Results}

A total of eight species of furcocercous cercariae was found in the four snail species studied. In Lymnaea stagnalis and Valvata macrostoma three species each were found, while one each species was in Bathyomphalus contortus and Planorbarius corneus. The most common species were Australapatemon burti (Miller, 1923) and Diplostomum pseudospathaceum (for prevalences see Table I). A. burti, Australapatemon sp., Cotylurus brevis Dubois et Rausch, 1950, Cercaria spinulosa Ginetsinskaya, 1959 and Sanguinicola sp. are new species records for Finland. Ichthyocotylurus variegatus (Creplin, 1825) and Bilharziella polonica (Kowalewski, 1895) were first recorded as cercariae in Finland.

\section{Descriptions of cercariae}

Diplostomidae Poirier, 1866

Diplostomum pseudospathaceum Niewiadomska, 1984

Host: Lymnaea stagnalis

Remarks: The morphology of the cercariae is identical to that described on material from Central Finland by Niewiadomska et al. (1997) (see also Niewiadomska 1986 for description and measurements). D. pseudospathaceum was reported already by Wikgren (1956) under the name D. spathaceum (Rudolphi, 1819). Niewiadomska et al. (1997) and Väyrynen et al. (2000) reported the cercariae as most common in Northern and Central Finland.

Strigeidae Railliet, 1919

Australapatemon burti (Miller, 1923) (Fig. 1A, B)

Host: Bathyomphalus contortus

Body of same length as tail stem, 120-150 (130) $\times 50-58$ (52); tail stem longer than furcae; seven pairs of caudal bodies in tail stem. Body spination confined to anterior part, reaches to level of intestinal bifurcation ventrally and to posterior edge of colourless eye-spots laterally; spines also present on tail stem and furcae. Pre-oral spines absent; post-oral spines arranged in 9 rows reaching to the mid-length of anterior organ, larger than body spines. Terminal anterior organ 38-43 $\times 25-$ $30(39 \times 26)$, of same width as ventral sucker. Ventral sucker post-equatorial, $25-30 \times 25-30(29 \times 28)$, with 3 rows of quite large spines. Colourless eye-spots, between level of intestinal bifurcation and ventral sucker. Prepharynx short, pharynx oval, $10-15 \times 10-13(12 \times 10)$; oesophagus as long as pharynx, bifurcates at half distance between pharynx and ventral sucker; caeca short, with 5 septa, reaching to posterior border of ventral sucker. Penetration gland-cells four pairs, posterior to ventral sucker, poorly visible. Anlagen of reproductive organs between penetration gland-cells and excretory bladder. Excretory bladder trilobed, with Cort's isle; flame-cell formula $2[(1+1)+(2+2+[1])]=14$; excretory system with incomplete commissure anterior to ventral sucker and complete commissure posterior to ventral sucker; caudal flamecells at level of first two pairs of caudal bodies (in first fifth of tail length).

Remarks: The morphology of the cercaria described above corresponds well to the description of Dubois (1968). A. burti is reported among the most common strigeid cercariae occurring in pulmonate snails in Europe (Dubois 1968, Blair 1977,

Table I. Molluscs examined/infected in Lake Konnevesi, Central Finland and prevalence of infection with cercariae

\begin{tabular}{|c|c|c|c|}
\hline \multirow{2}{*}{$\begin{array}{l}\text { Snail hosts } \\
\text { Cercariae species } \\
\end{array}$} & \multicolumn{2}{|c|}{ Snails } & \multirow[t]{2}{*}{ Prevalence (\%) } \\
\hline & examined & infected & \\
\hline Lymnaea stagnalis (Linnaeus, 1758) & 180 & & \\
\hline Diplostomum pseudospathaceum Niewiadomska, 1984 & & 18 & 10.0 \\
\hline Cotylurus brevis Dubois et Rausch, 1950 & & 6 & 3.3 \\
\hline Cercaria spinulosa Ginetsinskaya, 1959 & & 10 & 5.6 \\
\hline Valvata macrostoma Mörch, 1864 & 465 & & \\
\hline Australapatemon $\mathrm{sp}$. & & 6 & 1.3 \\
\hline Ichthyocotylurus variegatus (Creplin, 1825) & & 29 & 6.2 \\
\hline Sanguinicola sp. & & 15 & 3.2 \\
\hline Bathyomphalus contortus (Linnaeus, 1758) & 15 & & \\
\hline Australapatemon burti (Miller, 1923) & & 2 & 13.3 \\
\hline Planorbarius corneus (Linnaeus, 1758) & 12 & & \\
\hline Bilharziella polonica (Kowalewski, 1895) & & 1 & 8.3 \\
\hline Total & 672 & 87 & 12.9 \\
\hline
\end{tabular}




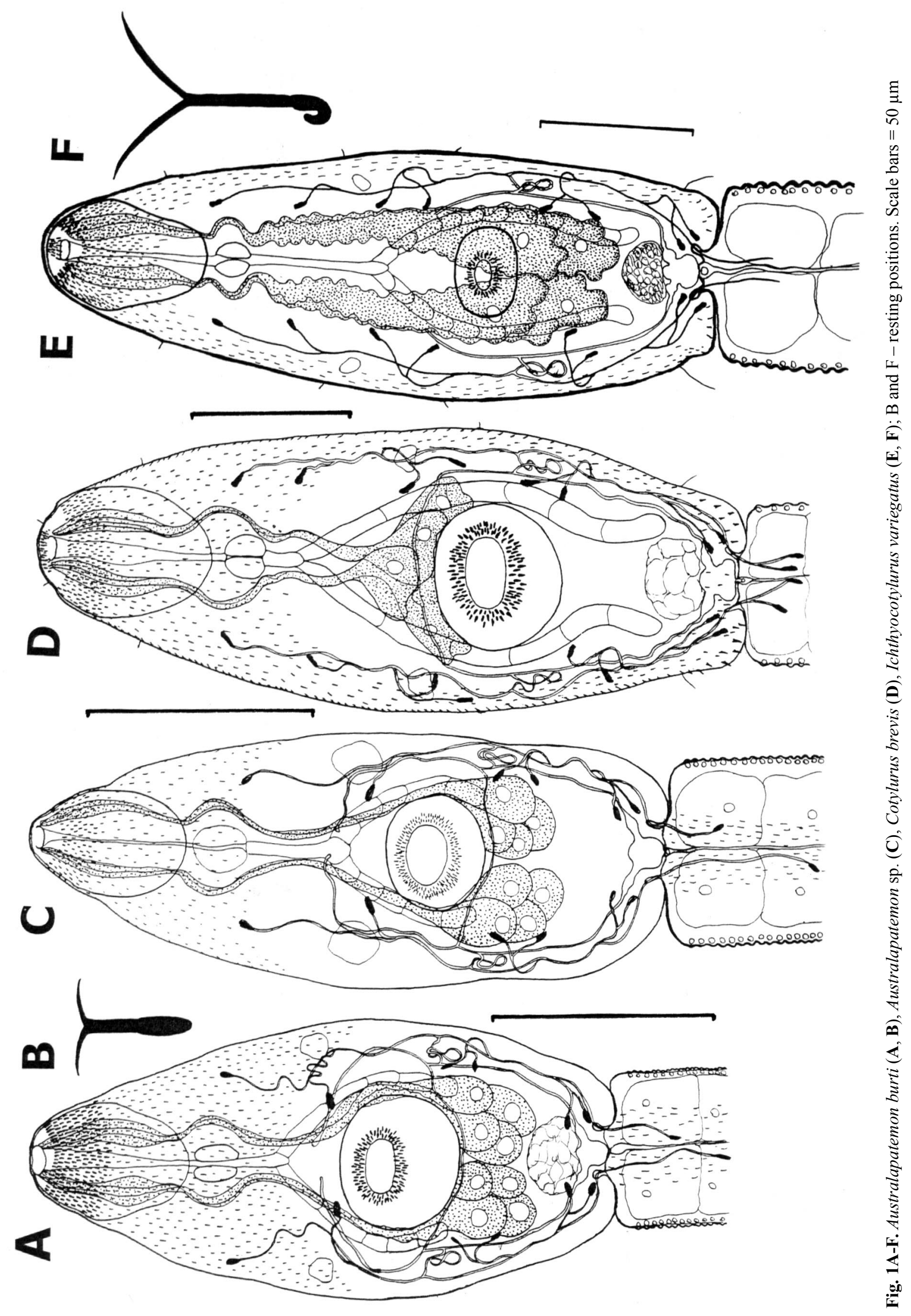


Combes 1980, Našincová 1992). However, it was long reported as Apatemon gracilis (Rudolphi, 1819), despite the fact that the cercariae can be easily distinguished by their morphology (different flame-cell formula and shape of intestine) and the life-cycle of A. gracilis was studied by Vojtek (1964).

\section{Australapatemon sp. (Fig. 1C)}

Host: Valvata macrostoma

Body slightly longer than tail stem, 128-160 (139) $\times 45-65$ (52). Tail stem 125-163 (154) × 35-45 (42); furcae longer than tail stem, 135-188 (180) by 15-23 (19). In tail stem six pairs of caudal bodies. Long, fine spines on anterior part of body reach to level of posterior border of pharynx ventrally and to level of anterior border of ventral sucker dorsally; tail stem and furcae spinose. Pre-oral spines absent; post-oral spines larger than body spines, in ca. 6 rows covering first third of anterior organ. Terminal anterior organ of same width as ventral sucker, $30-50 \times 23-30(37 \times 26)$. Ventral sucker post-equatorial $25-28 \times 23-25(27 \times 25)$, with 3 rows of 114-140 spines. Penetration gland-cells four pairs, posterior to ventral sucker, poorly visible. Large colourless eye-spots at level of intestinal bifurcation; prepharynx short, oval pharynx large, $13-18 \times 10-13(14 \times 11)$; oesophagus bifurcates in posterior third of forebody; caeca poorly visible, with probably 5 septa, reach to posterior border of ventral sucker. Excretory bladder trilobed, with Cort's isle; flame-cell formula $2[(1+1)+(2+2+[1])]=14$; excretory system with an incomplete anterior commissure at level of intestinal bifurcation and a complete commissure posterior to ventral sucker; caudal flame-cells in anterior third of tail stem.

Remarks: This cercaria corresponds well to the characteristics of the genus Australapatemon Sudarikov, 1959 in the shape of body, absence of pre-oral spines, shape and position of intestine, position of penetration gland-cells and flame-cell formula. In Europe four species of Australapatemon are known, A. burti (Miller, 1923) and A. minor (Yamaguti, 1933) using pulmonate snails as intermediate hosts, and $A$. anseris Dubois, 1967 and A. fuhrmanni (Dubois, 1937) with yet unknown life-cycles. It might be possible that this form relates to one of these latter species. So far, no species of Australapatemon have been reported to use prosobranch snails as intermediate hosts in Europe, except for Wesenberg-Lund (1934), who recorded a similar cercaria to the present one, Cercaria longiremis Wesenberg-Lund, 1934, in Valvata piscinalis from Denmark. Although this author did not illustrate the colourless eye-spots and some parts of the excretory system, which makes the comparison difficult, $C$. longiremis is larger, and differs from Australapatemon sp. in its body spination that reaches to the intestinal bifurcation; the post-oral spines reach to the posterior border of the anterior organ in the former.

\section{Cotylurus brevis Dubois et Rausch, 1950 (Fig. 1D) Host: Lymnaea stagnalis}

Body, tail stem and furcae of about same length; body 195-235 (218) × 50-63 (55); tail stem 212-227 (221) × 35-45
(37); furcae 202-227 (220) × 15-25 (18). Lateral sensory cilia on body (4 pairs) and tail stem (ca. 7 pairs). In tail stem seven pairs of caudal bodies. Spines on entire body except for the area surrounding ventral sucker, those close to posterior extremity of body larger; tail stem and furcae spinose. Pre-oral spines 20-28, arranged in 3 rows; post-oral spines larger than body spines, in 10 rows, cover first third of anterior organ. Terminal anterior organ of same width as ventral sucker, 40$48 \times 28-35(44 \times 30)$. Ventral sucker post-equatorial, 33-35 $\times 30-35(35 \times 32)$, with 134-137 large spines arranged in 3 rows. Small colourless eye-spots equatorial. Prepharynx present; pharynx oval, $13-20 \times 10-15(15 \times 13)$; oesophagus as long as pharynx, bifurcates at two thirds of forebody; caeca with six septa, reach close to anlagen of reproductive organs. Penetration gland-cells two pairs, anterior to ventral sucker, between caeca; can be temporarily para-acetabular. Anlagen of reproductive organs anterior to excretory bladder. Excretory bladder trilobed, with Cort's isle; flame-cell formula $2[(2+2)$ $+(2+2+[2])]=20$; excretory system with complete, equatorial commissure, anterior to ventral sucker, with a small protrusion; caudal flame-cells in tail stem immediately anterior.

Remarks: The morphological characters (flame-cell formula, two pairs of penetration gland-cells anterior to ventral sucker, oesophagus as long as pharynx, shape and position of caeca) of the present cercaria agree well to the description of Cotylurus brevis given in Dubois (1968). In the same snail host a similar cercaria of $C$. cornutus (Rudolphi, 1809) occurs. The cercariae can be distinguished from each other by the length of oesophagus (oesophagus as long as pharynx in C. brevis vs. oesophagus distinctly longer than pharynx in C. cornutus) and size of penetration gland-cells (smaller in C. brevis).

\section{Ichthyocotylurus variegatus (Creplin, 1825) (Fig. 1E, F) Host: Valvata macrostoma}

Body shorter than tail stem, 198-233 (214) $\times$ 43-60 (52); tail stem as long as furcae or slightly shorter, 242-313 (269) $\times$ 35-45 (40); furcae 232-328 (267) $\times 15-28$ (19). A total of 5 pairs of sensory cilia on lateral sides of body; sensillae present on tail and furcae. In tail stem six pairs of caudal bodies, the last 3 pairs can be arranged irregularly. Body spines small, reach to mid-level of anterior organ ventrally and to posterior extremity of body laterally; spines (ca. 10-14) on posterior ventral part of body larger. Tail stem without spines; furcae with spines. Pre-oral spines 16-18, arranged in 3 rows; postoral spines extend to mid-length of anterior organ, arranged in 12 rows, first 3 rows the largest. Anterior organ larger than ventral sucker, $42-50 \times 22-30(44 \times 26)$. Ventral sucker postequatorial, $20-30 \times 16-25(25 \times 21)$, with 54-100 spines of variable shape in irregular double row. Small colourless eyespots at half length between pharynx and ventral sucker. Prepharynx present, pharynx oval, $12-15 \times 10-14(13 \times 11)$; oesophagus bifurcates at last third of distance between pharynx and ventral sucker; caeca with 9-12 septa, reach to anlagen of reproductive organs. Penetration gland-cells two pairs, 
located between caeca posterior to ventral sucker, first pair can be pre- or para-acetabular; gland-cells large, with indentations. Anlagen of reproductive organs between penetration gland-cells and excretory bladder. Excretory bladder trilobed, with Cort's isle; excretory system with poorly visible commissure anterior to ventral sucker; flame-cell formula 2 [(2+ $2)+(2+2+[2])]=20$; three pairs of ciliary tufts in main collecting ducts; caudal flame-cells in the anterior half of tail stem.

Remarks: Cercariae of three (Ichthyocotylurus erraticus, I. platycephalus and I. variegatus) of the four currently recognized species of Ichthyocotylurus (Bell et al. 2001) have been described in Valvata piscinalis by Odening et al. (1970), Odening and Bockhardt (1971) and Swennen et al. (1979), and in Valvata macrostoma by Harrod and Griffiths (2005). Although the characters of I. variegatus and I. platycephalus (Creplin, 1825) overlap to a certain degree (snail host, size, relation of length of tail stem and furcae, number of septa in caeca, number of spines on ventral sucker) the morphology of the present cercariae agrees well with the description of $I$. variegatus by Odening and Bockhardt (1971). As the most reliable distinguishing characters can be considered the position of the first pair of penetration gland-cells (posterior to ventral sucker in I. platycephalus vs. distinctly more anterior in I. variegatus) and body spination (spines on entire body in I. platycephalus vs. lateral spines only in I. variegatus). In the present study, the identity of the cercariae was verified experimentally by exposure of fishes to cercariae. The infection of Perca fluviatilis, considered as a typical second intermediate host of I. variegatus (Odening and Bockhardt 1971), was successful, as were those of Stizostedion lucioperca and Gymnocephalus cernuus.

\section{Cercaria spinulosa Ginetsinskaya, 1959 (Fig. 2A, B)}

Host: Lymnaea stagnalis

Body of same length as tail stem, 153-168 (161) $\times 50-60$ (57); tail stem 165-175 (170) $\times 38-40(36)$; furcae slightly shorter than tail stem, 128-160 (144) $\times 15-18(17)$. A total of
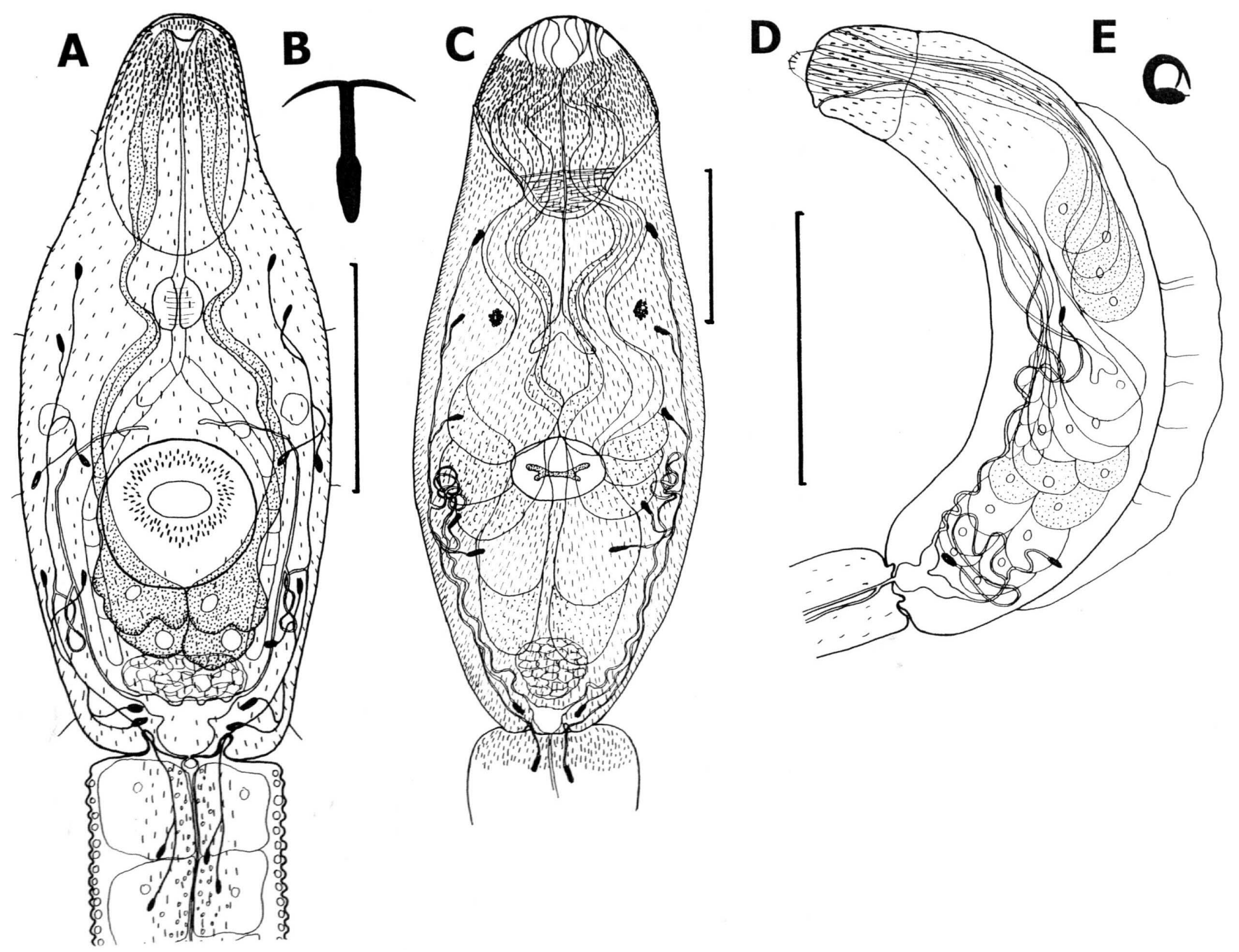

Fig. 2A-E. Cercaria spinulosa (A, B), Bilharziella polonica (C), Sanguinicola sp. (D, E); B and E - resting positions. Scale bars $=50 \mu \mathrm{m}$ 
5 pairs of sensory cilia laterally on body, on tail stem a group of cilia in the first and last third of tail and approximately one pair in its mid-length; 6-8 pairs of caudal bodies in tail. Quite large spines on entire body, tail stem and furcae, area around ventral sucker covered by smaller spines, no body spines on ventral sucker. Terminal anterior organ as wide as ventral sucker, $45-50 \times 25-33(47 \times 28)$. On anterior organ two rows of 12-19 pre-oral spines; post-oral spines arranged in 11-12 rows, larger than body spines, cover first third of anterior organ. Ventral sucker post-equatorial, $30-35 \times 25-33(32 \times$ 30 ), with 3 (sometimes 4) rows of ca. 150 spines. Small colourless eye-spots between level of intestinal bifurcation and ventral sucker. Prepharynx distinct, pharynx spherical, $13-18 \times 10-15(15 \times 13)$; oesophagus short, as long as pharynx, intestinal bifurcation in first half of distance between pharynx and ventral sucker; caeca with 7-8 septa, reaching close to anlagen of reproductive organs. Penetration glandcells two pairs, posterior to ventral sucker. Anlagen of reproductive organs between penetration gland-cells and excretory bladder. Excretory bladder trilobed, with Cort's isle; flamecell formula $2[(2+2)+(2+2+[2])]=20$; three pairs of ciliary tufts in main collecting ducts; excretory system with incomplete commissure, anterior to ventral sucker. Caudal flame-cells in anterior third of tail stem.

Remarks: Cercaria spinulosa has so far been reported in Lymnaea stagnalis from Russia by Ginetsinskaya (1959) and in L. stagnalis, L. palustris and Radix auricularia from the Czech Republic by Zajíček and Valenta (1964). Odening et al. (1970) suggested that this species could belong to the genus Ichthyocotylurus according to its morphology (flame-cell formula, location of the commissure of main collecting ducts anterior to ventral sucker and number and position of penetration gland-cells). However, Ginetsinskaya (1959) reported that although experimentally $C$. spinulosa penetrated into fish (Abramis brama, Rutilus rutilus), newts and leeches, no metacercariae developed. In contrast, Zajíček and Valenta (1964) infected leeches (Herpobdella atomaria), but their attempts to infect pigeons with metacercariae were not successful. In the present study experimental infections carried out with fish (Perca fluviatilis, Stizostedion lucioperca) also failed.

Schistosomatidae Stiles et Hassall, 1898

Bilharziella polonica (Kowalewski, 1895) (Fig. 2C)

Host: Planorbarius corneus

Remarks: The morphology of the cercaria agrees well to descriptions of Iles (1959), Našincová (1992), WesenbergLund (1934) and Zdun (1959).

Sanguinicolidae von Graff, 1907

Sanguinicola sp. (Fig. 2D, E)

Host: Valvata macrostoma

Body shorter than tail, 125-145 (133) $\times 38-48(41)$; tail stem 215-263 (245) × 28-38 (29); short furcae 63-93 (72) × 10-18 (15), possess fin-folds. Body with dorsal crista originating in ca. second third of body length (65) and terminating in the last sixth of body length. Five rows of large spines cover the first half of anterior organ; fine body spines reach to the origin of dorsal crista; large spines on tail stem and furcae. Mouth opening subterminal, anterior organ with protrusible dorsal tip, 25-30 × 23-28 $(28 \times 25)$. Intestine irregularly sac-like, terminating equatorially. Eight to 11 (usually 10) pairs of poorly visible large gland-cells with terminal outlets; those in equatorial and posterior parts of body transparent, do not stain with Nile blue; in mid-length of body small cells of indefinable number. Body filled with small cells, therefore all structures poorly visible. Excretory bladder Y-shaped, flame-cell formula $2[1+1]=4$.

Remarks: The morphological characters (dorsal crista, absence of ventral sucker, anterior organ well differentiated from body and with protrusible tip, doubled excretory duct in tail stem) of the present cercaria correspond well to the genus Sanguinicola Plehn, 1905. In Europe, four species of Sanguinicola are known, two (S. inermis Plehn, 1905 and S. intermedia Ejsmont, 1925) using pulmonate snails, $S$. volgensis (Rašín, 1929) with unknown life-cycle (Niewiadomska 2003), and only S. armata Plehn, 1905 recorded in a prosobranch host (Bithynia leachii) by Ejsmont (1925).

The cercariae of the present species develop in round sporocysts, which applies also for those of $S$. armata observed by Ejsmont (1925). However, the species identity of the present cercaria cannot be elucidated due to both, the high similarity of the cercariae of the species of Sanguinicola and the existing incomplete descriptions. Those cercariae found in $V$. piscinalis by Filippi (1859), Wesenberg-Lund (1934) and Chernogorenko (1983) were either regarded as the wellknown S. inermis Scheuring, 1922, or considered as a complex of species. Therefore, obtaining adults in experiments is necessary for reliable species identification. However, our experiments to obtain adults for verification of the species identity failed.

\section{Discussion}

Cercariae of five species of the family Strigeidae and one each from the families Diplostomidae, Schistosomatidae and Sanguinicolidae, were found in Lake Konnevesi in Central Finland. Of these, five are new species records for Finland and seven represent a first record of cercariae.

Adults of Bilharziella polonica were previously found in anseriform birds in the Northeast Bothnian Bay and the Baltic Sea (Brglez and Valtonen 1987), metacercariae of Ichthyocotylurus variegatus were reported from fish in Central Finland and the Bothnian Bay (Valtonen et al. 2001, 2003; Karvonen et al. 2005). Except for Sanguinicola sp., which matures in fish, all present species use birds as the definitive hosts.

Concerning the snail hosts, Lymnaea stagnalis and Planorbarius corneus are known as suitable intermediate hosts harbouring a wide spectrum of larval trematodes (Faltýnková and Haas 2006), whereas there are few records of cercariae 
occurring in Valvata, which are limited to $V$. piscinalis. Our study represents the first host record of $V$. macrostoma for larval stages of Australapatemon sp. and Sanguinicola sp.

Our findings and those of metacercariae and adult trematodes in birds (Brglez and Valtonen 1987; Karvonen et al. 2006b) imply that there are potentially more species in Central Finland, especially of the family Strigeidae Railliet, 1919, than were found until now.

Acknowledgements. We acknowledge Anssi Karvonen, Otto Seppälä, Eero Mantila and José Carlos Pedro for technical support and mollusc sampling, and Aneta Kostadinova for helpful comments to improve the manuscript. This study was supported by the Grant Agency of the Academy of Sciences of the Czech Republic (project No. IAA6022404), the Grant Agency of the Czech Republic (projects Nos. 524/03/H133, 524/07/P086), the research projects of the Institute of Parasitology, ASCR (Z60220518 and LC522) and the Grant of the Portuguese FCT N ${ }^{\circ}$ SFRH/BSAB/492/2005.

\section{References}

Bell A.S., Sommerville C., Valtonen E.T. 2001. A molecular phylogeny of the genus Ichthyocotylurus (Digenea, Strigeidae). International Journal for Parasitology, 31, 833-842. DOI: 10.1016/S0020-7519(01)00181-3.

Blair D. 1977. A key to cercariae of British strigeoids (Digenea) for which the life-cycles are known, and notes on the characters used. Journal of Helminthology, 51, 155-166.

Brglez J., Valtonen E.T. 1987. Trematodes in some anseriform birds from the Island of Hailuoto in the Bay of Bothnia (Finland). Veterinarski Arhiv, 57, 177-182.

Chernogorenko M.I. 1983. Larval trematodes in molluscs of Dnepr and its water reservoirs. Naukova Dumka, Kiev, 212 pp. (In Russian).

Combes C. 1980. Atlas Mondial des Cercaires. Mémoires du Muséum National d'Histoire Naturelle, Sér. A, Zoologie, 115 , $5-235$.

Dubois G. 1968. Synopsis des Strigeidae et des Diplostomatidae (Trematoda). Mémoires de la Société Neuchâteloise des Sciences Naturelles, 10, 1-270.

Ejsmont M.L. 1925. Morphologische, systematische und entwicklungsgeschichtliche Untersuchungen an Arten des Genus Sanguinicola Plehn. Bulletin International de l'Academie Polonaise des Sciences Naturelles et des Lettres, Ser. B, Sciences Naturelles, 6, 877-964.

Faltýnková A., Haas W. 2006. Larval trematodes in freshwater molluscs from the Elbe to Danube rivers (South-East Germany): before and today. Parasitology Research, 99, 572-582. DOI: 10.1007/s00436-006-0197-9.

Filippi P. de 1859. Troisiéme mémoire pour servir a l'historie génétique des Trématodes. Mémoires de l'Académie des Sciences Torino, 18, 201-232.

Gibson D.I., Jones A., Bray R.A. 2002. Keys to the Trematoda. Volume 1. CABI Publishing and Natural History Museum, Wallingford, UK, $521 \mathrm{pp}$.

Gibson D.I., Taskinen J., Valtonen E.T. 1992. Studies on bucephalid digeneans parasitising molluscs and fishes in Finland. II. The description of Rhipidocotyle fennica $\mathrm{n}$. sp. and its discrimination by principal components analysis. Systematic Parasitology, 23, 67-79.

Ginetsinskaya T.A. 1959. On the fauna of cercariae from molluscs in the Rybinsk water reservoir. Part I. Systematic survey of cercariae. Ekologicheskaya Parazitologiya, 96-149 (In Russian).
Glöer P. 2002. Die Süßwassergastropoden Nord- und Mitteleuropas. Bestimmungschlüssel, Lebensweise, Verbreitung. Die Tierwelt Deutschlands, 73, 1-327.

Harrod C., Griffiths D. 2005. Ichthyocotylurus erraticus (Digenea: Strigeidae): factors affecting infection intensity and the effects of infection of pollan (Coregonus autumnalis), a glacial relict fish. Parasitology, 131, 511-519. DOI: 10.1017/S00 31182005007985.

Holopainen I.J., Lamberg S., Valtonen E.T., Rantanen J. 1997. Effects of parasites on life history of the freshwater bivalve, Pisidium amnicum, in Eastern Finland. Archiv für Hydrobiologie, 139, 461-477.

Iles C. 1959. The larval trematodes of certain fresh-water molluses. I. The furcocercariae. Parasitology, 49, 478-504.

Karvonen A., Cheng G.H., Valtonen E.T. 2005. Within-lake dynamics in the similarity of parasite assemblages of perch (Perca fluviatilis). Parasitology, 131, 817-823. DOI: 10.1017/S00 31182005008425.

Karvonen A., Kirsi S., Hudson P.J., Valtonen E.T. 2004. Patterns of cercarial production from Diplostomum spathaceum: terminal investment or bet hedging? Parasitology, 129, 87-92. DOI: $10.1017 /$ S0031182004005281.

Karvonen A., Savolainen M., Seppälä O., Valtonen E.T. $2006 \mathrm{a}$. Dynamics of Diplostomum spathaceum infection in snail hosts at a fish farm. Parasitology Research, 99, 341-345. DOI: 10.1007/s00436-006-0137-8.

Karvonen A., Terho P., Seppälä O., Jokela J., Valtonen E.T. 2006b. Ecological divergence of closely related Diplostomum (Trematoda) parasites. Parasitology, 133, 229-235. DOI: 10.1017/ S0031182006000242.

Našincová V. 1992. Trematode developmental stages in Czech aquatic snails and life-cycles of selected species of the family Omphalometridae and Echinostomatidae. PhD Thesis, Institute of Parasitology, Czechoslovak Academy of Sciences, České Budějovice (In Czech).

Niewiadomska K. 1986. Verification of the life-cycles of Diplostomum spathaceum (Rudolphi, 1819) and D. pseudospathaceum Niewiadomska, 1984 (Trematoda, Diplostomidae). Systematic Parasitology, 8, 23-31.

Niewiadomska K. 2003. Monografie Parazytologiczne. 15. Pasożyty ryb Polski (klucze do oznaczania): Przywry - Digenea. Polskie Towarzystwo Parazytologiczne, Warszawa (In Polish).

Niewiadomska K., Valtonen E.T., Siddall R. 1997. Cercariae from Lymnaea stagnalis in lake Kuuhankavesi (central Finland). Acta Parasitologica, 42, 132-137.

Odening K., Bockhardt I. 1971. Der Lebenszyklus des Trematoden Cotylurus variegatus im Spree-Havel-Seengebiet. Biologisches Zentralblatt, 90, 49-84.

Odening K., Mattheis T., Bockhardt I. 1970. Der Lebenszyklus von Cotylurus c. cucullus (Thoss) (Trematoda, Strigeida) im Raum Berlin. Zoologische Jahrbücher, Abteilung für Systematik, 97, 125-198.

Rantanen J.T., Valtonen E.T., Holopainen I.J. 1998. Digenean parasites of the bivalve mollusc Pisidium amnicum in a small river in eastern Finland. Diseases of Aquatic Organisms, 33, 201-208.

Swennen C., Heessen H.J.L., Höcker A.W.M. 1979. Occurrence and biology of the trematodes Cotylurus (Ichthyocotylurus) erraticus, $C$. (I.) variegatus and C. (I.) platycephalus (Digenea: Strigeidae) in the Netherlands. Netherlands Journal of Sea Research, 13, 161-191. DOI:10.1016/0077-7579(79)90001-2.

Taskinen J., Mäkelä T., Valtonen E.T. 1997. Exploitation of Anodonta piscinalis (Bivalvia) by trematodes: Parasite tactics and host longevity. Annales Zoologici Fennici, 34, 37-46.

Taskinen J., Valtonen E.T., Gibson D.I. 1991. Studies on bucephalid digeneans parasitising molluses and fishes in Finland. I. Ecological data and experimental studies. Systematic Parasitology, 19, 81-94. 
Taskinen J., Valtonen E.T., Mäkelä T. 1994. Quantity of sporocysts and seasonality of two Rhipidocotyle species (Digenea: Bucephalidae) in Anodonta piscinalis (Mollusca: Bivalvia). International Journal for Parasitology, 24, 877-886.

Valtonen E.T., Holmes J.C., Aronen J., Rautalahti I. 2003. Parasite communities as indicators of recovery from pollution: parasites of roach (Rutilus rutilus) and perch (Perca fluviatilis) in Central Finland. Parasitology, 126, S43-S52. DOI: 10.1017/ S0031182003003494.

Valtonen E.T., Pulkkinen K., Poulin R., Julkunen M. 2001. The structure of parasite component communities in brackish water fishes of the northeastern Baltic Sea. Parasitology, 122, 471-481. DOI: 10.1017/S0031182001007491.

Väyrynen T., Siddall R., Valtonen E.T., Taskinen J. 2000. Patterns of trematode parasitism in lymnaeid snails from northern and central Finland. Annales Zoologici Fennici, 37, 189-199.
Vojtek J. 1964. Zur Kenntnis des Entwicklungszyklus von Apatemon cobitidis (Linstow, 1890). Zeitschrift für Parasitenkunde, 24, 578-599.

Wesenberg-Lund C. 1934. Contributions to the development of the Trematoda Digenea. Part II. The biology of the freshwater cercariae in Danish freshwaters. Mémoires de l'Academie Royale des Sciences et des Lettres de Danemark, Copenhague, Section des Sciences, 9, 3-223.

Wikgren B.J. 1956. Studies on finnish larval flukes with a list of known finnish adult flukes (Trematoda: Malacocotylea). Acta Zoologica Fennica, 91, 1-106.

Zajíček D., Valenta Z. 1964. Contribution on the occurrence of furcocercariae in some areas of Czechoslovakia. Ceskoslovenská Parasitologie, 11, 273-293 (In Czech).

Zdun W. 1959. Cercariae from Coretus corneus (L.) in the environments of Warszawa. Acta Parasitologica Polonica, 7, 95115. 